\title{
DESAIN E-BOOK DENGAN SOFTWARE FLIPBOOKMAKER UNTUK PEMBELAJARAN MATA KULIAH AKUNTANSI KEUANGAN DI STEKOM SEMARANG
}

\author{
Siti Kholifah \\ Komputerisasi Akuntansi STEKOM Semarang \\ Sekolah Tinggi Elektronika dan Komputer \\ Jl. Majapahit 605 \& 304 Semarang, Indonesia \\ e-mail:olivstekom@gmail.com
}

\begin{abstract}
:
The purpose of this study is developing e-Book for learning financial accounting with valid criteria. This study is a Research and Development. The development of research using a modification of the 4D model into 3D with the define (definition), design (planning), and development (development). E-Book financial accounting subject first tested the validation by media experts, subject matter experts and also questionnaire responses of college students. Retrieved scoring average $85.2 \%$ validation of subject matter experts, media expert validation $89.2 \%, 85.2 \%$ votes college student responses, so a decent media E-book is used with very good category.
\end{abstract}

Keywords: Development, $e$ - book, financial accounting

\begin{abstract}
Abstrak
Tujuan penelitian ini adalah untuk mengembangkan produk e-book untuk pembelajaran mata kuliah akuntansi keuangan yang valid. Penelitian ini merupakan penelitian Research and Development. Penelitian pengembangan ini menggunakan modifikasi model 4D menjadi 3D dengan tahap define (pendefinisian), design (perencanaan), dan development (pengembangan). E-book dengan software flopbookmaker terlebih dahulu dilakukan uji validasi oleh ahli media, ahli materi dan juga angket tanggapan mahasiswa. Diperoleh rata-rata penilaian validasi ahli materi $85,2 \%$, validasi ahli media $89,2 \%$, penilaian tanggapan mahasiswa $85,2 \%$, Jadi media E-book layak digunakan dengan kategori sangat baik.
\end{abstract}

Kata Kunci: Pengembangan, e-book, akuntansi keuangan 


\section{PENDAHULUAN}

Akuntansi Keuangan adalah serangkaian proses yang berujung pada penyusunan laporan keuangan yang berkaitan dengan perusahaan secara keseluruhan untuk digunakan oleh pengguna laporan keuangan baik internal maupun eksternal perusahaan (intermediate Accounting: 2000). Untuk menunjang kemampuan mahasiswa dalam memahami materi akuntansi keuangan dan membuat laporan keuangan diperlukan terobosan yang harus dilakukan dosen dalam mengajar, salah satunya adalah mengemas media pembelajaran yang menarik dan disesuaikan dengan perkembangan jaman.

.Berdasarkan wawancara informal yang dilakukan peneliti dengan salah satu dosen akuntansi keuangan di STEKOM Semarang diperoleh informasi didalam pembelajaran akuntansi keuangan mahasiswa belum dibekali dengan ebook atau e-modul, sehingga semua materi masih dikemas dalam versi cetak, sehingga perlu dilakukan inovasi salah satunya dengan membuat bahan ajar berupa e-book, untuk pengembangan bahan ajar ini didasari oleh Saglam (2011) yang menjelaskan penggunaan bahan ajar menjadikan proses belajar mengajar menjadi lebih mudah, efisien dan menjadikan mahasiswa cepat didalam menangkap materi pembelajaran.

Media merupakan sarana komunikasi (Russell; 2011). Menurut Buchori, dkk (2014) media adalah bagian penting dari belajar dalam proses pembelajaran. Pembelajaran dengan e-book merupakan pembelajaran dengan menggunakan elektronik book yang dalam implementasinya memanfaatkan media elektronik,. (wena: 2011). Adapun ciri e-book adalah dapat menyajikan deskripsi materi pelajaran yang mudah dimengerti, perangkat pembelajaran e-book memberikan kesempatan kesempatan kepada mahasiswa untuk melakukan praktik kegiatan pembelajaran. (Siagian, 2014:46)

Hasil penelitian Suarsana (2013) menunjukkan bahwa melalui penggunaan e-book didalam pembelajaran, kemampuan berfikir kritis dan hasil belajar mahasiswa mengalami peningkatan yang signifikan dari rata-rata 27,6 (sedang) pada siklus I menjadi 3,14 (tinggi) pada siklus II dan diperoleh nilai e-book adalah 75,5. Berdasarkan kriteria e-book berada dalam kategori baik. Bertentangan dengan itu, beberapa peneliti menemukan bahwa bahan ajar berupa e-book tidak selamanya mampu meningkatkan kemampuan berfikir kritis mahasiswa. Caroline (2013) menyatakan bahwa penggunaan e-book akan menurunkan hasil belajar mahasiswa jika tidak adanya penyiapan yang matang didalam lingkungan dan fasilitas belajar mahasiswa, yang meliputi tidak tersedianya sumber daya intruksional media.

Salah satu aplikasi komputer yang dapat digunakan dalam belajar akuntansi keuangan ini adalah software Flipbookmaker. Flipbookmaker merupakan perangkat lunak yang dinamis, bebas, dan multi-platform yang menggabungkan teks, gambar, video, animasi dan lain-lain yang dikemas secara bagus dan rapi sehingga mampu membuat mahasiswa dan dosen tertarik untuk meggunakannya.

agus dan rapi sehingga mampu membuat mahasiswa dan dosen tertarik untuk meggunakannya.

\section{TELAAH PUSTAKA}

\section{Media Pembelajaran}

Pembelajaran merupakan kombinasi yang tersusun meliputi unsur-unsur manusiawi, material, fasilitas, perlengkapan, dan prosedur yang saling mempengaruhi untuk mencapai tujuan pembelajaran (Hamalik 2001: 57). Pemakaian media pembelajaran dalam proses belajar mengajar dapat membangkitkan keinginan dan minat yang baru, membangkitkan motivasi dan rangsangan kegiatan belajar, dan membawa pengaruh-pengaruh psikologis terhadap mahasiswa. Selain membangkitkan motivasi dan minat mahasiswa, media pembelajaran dapat membantu mahasiswa meningkatkan pemahaman, menyajikan data dengan menarik dan terpercaya, memudahkan penafsiran data, dan memadatkan informasi. Berdasarkan pengertian yang telah diberikan, maka media pembelajaran merupakan segala sesuatu yang dapat digunakan dalam kegiatan pembelajaran untuk merangsang pikiran, perasaan, minat dan perhatian siswa sehingga proses interaksi antara dosen dan mahasiswa berlangsung secara tepat guna. 
Menurut Gerlach dan Ely (dalam Arsyad, 2002:11) ciri media pendidikan yang layak digunakan dalam pembelajaran adalah sebagai berikut,

\section{a. $\quad$ Fiksatif (fixative property)}

Media pembelajaran mempunyai kemampuan untuk merekam, menyimpan, melestarikan, dan merekonstruksi suatu peristiwa/objek.

\section{b. Manipulatif (manipulative property)}

Kejadian yang memakan waktu berhari-hari dapat disajikan kepada siswa dalam waktu dua atau tiga menit dengan teknik pengambilan gambar timelapse recording.

\section{c. Distributif (distributive property)}

Memungkinkan berbagai objek ditransportasikan melalui suatu tampilan yang terintegrasi dan secara bersamaan objek dapat menggambarkan kondisi yang sama pada mahasiswa dengan stimulus pengalaman yang relatif sama tentang kejadian itu.

Media pembelajaran memiliki beberapa fungsi dan manfaat, diantaranya :

a. Media pembelajaran dapat mengatasi keterbatasan pengalaman yang dimiliki oleh para mahasiswa. Jika peserta didik tidak mungkin dibawa ke obyek langsung yang dipelajari, maka obyeknya yang dibawa ke peserta didik. Obyek dimaksud bisa dalam bentuk nyata, miniatur, model, maupun bentuk gambar - gambar yang dapat disajikan secara audio visual dan audial.

b. Media pembelajaran dapat melampaui batasan ruang kelas. Melalui penggunaan media yang tepat, maka semua obyek itu dapat disajikan kepada mahasiswa.

c. Media pembelajaran memungkinkan adanya interaksi langsung antara mahasiswa dengan lingkungannya.

d. Media dapat menanamkan konsep dasar yang benar, konkrit, dan realistis.

e. Media membangkitkan keinginan dan minat baru.

f. Media membangkitkan motivasi dan merangsang anak untuk belajar. g. Media memberikan pengalaman yang integral/menyeluruh dari yang konkrit sampai dengan abstrak.

Menurut Sadiman dkk. ( 2006: 100), urutan untuk mengembangkan media pendidikan adalah sebagai berikut:

a. Menganalisis kebutuhan dan karakteristik siswa;

b. Merumuskan tujuan instruksional;

c. Merumuskan butir-butir materi secara terperinci yang mendukung tercapainya tujuan;

d. Mengembangkan alat pengukur keberhasilan;

e. Menulis naskah media;

f. Mengadakan tes dan revisi.

\section{Software Flipbook Maker}

Kvisoft Flipbook Maker menawarkan cara yang profesional tapi mudah untuk merancang animasi 3D halaman publikasi dari PDF, dokumen Microsoft Office, gambar, dan film flash. Sebuah perangkat lunak majalah digital bagi siapa saja untuk menghasilkan kreasi penerbitan digital seperti majalah/buku elektronik, katalog untuk meningkatkan presentasi online. Software pembuat majalah/buku digital Kvisoft Flipbook Maker memungkinkan konversi PDF ke HTML5, halaman majalah, flippable dengan kompatibilitas tinggi terhadap semua perangkat mobile yang populer: iPad, iPhone, iPod Touch, Android dan perangkat portaable lainnya. Pembacanya dapat menonton video, browsing gambar, mendengarkan musik, klik link dll pada perangkat mobile sama halnya seperti membaca halaman publikasi turnable/flippable pada komputer.

Kvisoft Flipbook Maker dapat mengkonversi gambar, SWF, flash video, dan file doc umum (PDF, Word, Excel, PowerPoint) untuk majalah 3D Flash dinamis yang diterbitkan online. Pengunjung dapat berbagi lebih mengesankan dan efektif. Anda tidak perlu tahu script Flash untuk membuat online e-magazine profesional untuk memberikan tips, merek, produk dan cerita ke seluruh dunia. Kvisoft Flipbook Maker dapat membuat halaman flash majalah/buku digital flippable interaktif dengan menanamkan berbagai media seperti teks dinamis, gelembung, galeri 
foto, flash, film lokal, video YouTube, musik, gambar Flickr, bentuk dan lain-lain.

\section{METODE PENELITIAN}

Jenis Penelitian

Penelitian ini merupakan penelitian pengembangan. Menurut Setyosari (2015:115) pengembangan adalah mengembangkan suatu produk tertentu, rancangan atau desain, strategi, pendekatan, atau suatu model. Penelitian ini merupakan pengemba-ngan E-book dengan pendekatan PMR berbantuan visualisasi geogebra yang mengacu pada model 4-D dengan beberapa modifikasi. (Hamdani, 2011: 27). Desain pembelajaran model 4-D terdiri atas empat tahap utama, yaitu Define (pendefinisian), Design (perancangan), Develop (pengem-bangan), dan Disseminate (penyebaran ;Peneliti tidak melakukan tahap disseminate, karena waktu dan target penelitian terbatas sehingga peneliti hanya melakukan sampai pada uji terbatas).

\section{Subyek dan Waktu Penelitian}

Subyek penelitian dalam ujicoba terbatas adalah berasal dari mahasiswa jurusan komputerisasi akuntansi semester ganjil tahun ajaran 2014/2015 di STEKOM Semarang

\section{Prosedur Pengembangan}

Prosedur pengembangan e-book dalam penelitian ini mengacu pada pengembangan 4-D. Pada desain pembelajaran model 4-D, peneliti mengambil langkah sampai tahap ketiga yaitu develop (pengembangan).

Secara garis besar, ketiga tahap langkah tersebut sebagai berikut (Hamdani, 2011:27-30):

\section{Tahap pendefinisian (define)}

Tujuan tahap ini adalah menetapkan dan mendefinisikan syarat-syarat pembelajaran diawali dengan analisis tujuan dari batasan materi yang dikembangkan perangkatnya. tahap ini meliputi lima langkah pokok, yaitu analisis awal dan akhir, analisis siswa, analisis materi, analisis tugas, dan perumusan tujuan pembelajaran.
2. Tahap perencanaan (design)

Tujuan tahap ini adalah menyiapkan prototipe perangkat pembelajaranTahap

$$
\text { 3. Pengembangan (develop) }
$$

Tujuan tahap ini adalah menghasilkan perangkat pembe-lajaran yang sudah direvisi berdasarkan masukan dari pakar.

\section{Teknik Pengumpulan Data}

Adapun teknik pengumpulan data adalah sebagai berikut:

Istrumen yang digunakan dalam validasi ahli ini adalah lembar validasi. Adapaun lembar validasi yang diperlukan adalah sebagai berikut:

1) Lembar validasi ahli materi

Lembar validasi ahli materi merupakan lembar yang ditujukan kepada ahli materi pembelajaran matematika. Dalam hal ini ahli materi adalah dosen universitas PGRI Semarang dan dosen STEKOM Semarang. Ahli tersebut akan memvalidasi tentang materi yang ada pada produk yang hasilnya berupa isi materi dalam e-book.

2) Lembar validasi ahli media

Lembar validasi ahli media merupakan lembar yang ditujukan kepada ahli media. Ahli media menilai pada tampilan produk, konsistensi e-book, format e-book dan daya tarik e-book.

3) Lembar Kuesioner (Angket)

Kuesioner merupakan teknik pengumpulan data yang dilakukan dengan cara memberi seperangkat pertanyaan atau pernyataan tertulis kepada responden untuk dijawabnya. Instrumen angket ini menggunakan skala Likert. Pada penelitian ini angket digunakan untuk mengetahui besarnya respon mahasiswa setelah mereka menggunakan e-book dalam pembelajaran.

\section{Teknik Analisis Data}

Data kuantitatif skor penilaian yang diperoleh dari hasil pengisian kuisioner (angket) ahli media dan ahli materi bidang studi dianalisis dengan acuan yang diadaptasi dengan menggunakan skala Likert 
yang nantinya akan dideskripsikan secara kualitatif.

Menurut Arikunto (2013:195) skala Likert disusun dalam bentuk suatu pernyataan dan diikuti oleh lima respon yang menunjukan tingkatan. Pada penelitian ini skala yang digunakan adalah: Sangat baik (SB) dengan skor 5, Baik (B) dengan skor 4, Cukup baik (CB) dengan skor 3, Kurang baik (KB) dengan skor 2, Tidak baik (TB) dengan skor 1. Dalam penelitian pengembangan ini, skor penelitian dapat tercapai apabila rata-rata penilaian dari tiap item indikator kuisioner (angket) dalam kategori tinggi. Indikator kategori untuk tiap item indikator kuisioner (angket) dikatakan tinggi (T) jika nilainya $\geq 3$ dan dikatakan dalam kategori rendah (R) jika nilainya $<3$.Untuk menganalisis data dari kuisioner (angket) dilakukan langkah-langkah sebagaimana yang telah dijelaskan Arikunto (2009: 265) dalam analisis deskriptif kualitatif sebagai berikut.

a) Langkah1: Penelitian menjumlah-kan tanda centang yang ada pada setiap kolom untuk kemudian dicari besarnya persentase untuk masing-masing kategori.

b) Langkah2: Menjumlahkan banyak-nya tanda centang pada setiap kolom yang terdapat matriks alat bantu. Jumlah tersebut dibandingkan dengan jumlah seluruh uraian materi kemudian dicari persentasenya.

c) Langkah 3: Menuliskan besarnya prosentase dalam setiap kolom.

Untuk dapat memberikan makna dan pengambilan keputusan, digunakan ketetapan sebagai indikator keberhasilan validasi ahli media pembelajaran dan materi. Pada uji ahli media pembelajaran dan materi, hasil persentase setiap item dikatakan berhasil atau valid bila hasil yang berada pada rentang $81 \%$ - 100\%, 61\% - 80\%, ataupun pada rentang $41 \%$ - $60 \%$ yaitu pada kriteria "sangat baik", "baik", atau "cukup".

\section{HASIL PENELITIAN DAN PEMBAHASAN}

\section{Hasil Penelitian}

\section{Define (Pendefinisian)}

Adapun persiapan-persiapan yang dilakukan sebelum penelitian yang merupakan tahap define pada prosedur pengembangan 4D adalah sebagai berikut:

Melakukan observasi dan konsultasi dengan dosen pengampu mata kuliah akuntansi keuangan di STEKOM Semarang. Dimana dalam observasi proses pembelajaran, peneliti mengidentifikasi bahwa terdapat kekurangan dalam proses pembelajaran.

\section{Design (Perencanaan)}

Pada tahap ini merupakan tahap design pada prosedur pengembangan 4-D. Dalam tahap desain produk ini peneliti membuat rancangan desain untuk mengembangkan e-book dengan aplikasi flipbookmaker yang akan digunakan sebagai media pembelajaran. Hal-hal yang diperlukan dalam menyusun produk tersebut adalah menetapkan mata kuliah yang akan dikembangkan yaitu dengan fokus pembuatan laporan keuangan secara sistematis.

Tahap selanjutnya adalah pengumpulan data bahan atau materi kuliah yang diperlukan untuk pembuatan produk seperti: materi pokok (subtansi mata kuliah akuntansi keuangan), aspek pendukung seperti gambar dan lain-lain. Pengumpulan materi pokok dilakukan dengan menggunakan sumber-sumber atau buku-buku kuliah, sedangkan pengumpulan gambar diperoleh melalui download melalui internet. Tahap terakhir adalah pembuatan produk yaitu ebook dengan software flipbookmaker

\section{Develop (Pengembangan)}

\section{Validasi Ahli}

Pada tahap ini merupakan tahap develop pada prosedur pengembangan 4-D. Produk media pembelajaran berupa e-book dengan software flipbookmaker sebagai hasil dari pengembangan ini diuji tingkat validitas dan kepraktisannya. Tingkat validitas media pembelajaran diketahui melalui hasil analisis kegiatan uji coba.

\section{Hasil Validasi Media}

Analisis ahli media ditinjau dari aspek:

1) aspek umum,

2) aspek penyajian pembelajaran,

3) aspek kelayakan bahasa, dan 
4) aspek kelayakan kegrafikan.

Berdasarkan perhitungan, diketahui prosentase $=$ $85,2 \%$, setelah dikonversikan dengan tabel konversi skala, prosentase tingkat pencapaian
$85,2 \%$ berada pada kualifikasi sangat baik sehingga media pembelajaran layak diuji cobakan dengan memerlukan revisi sedikit.

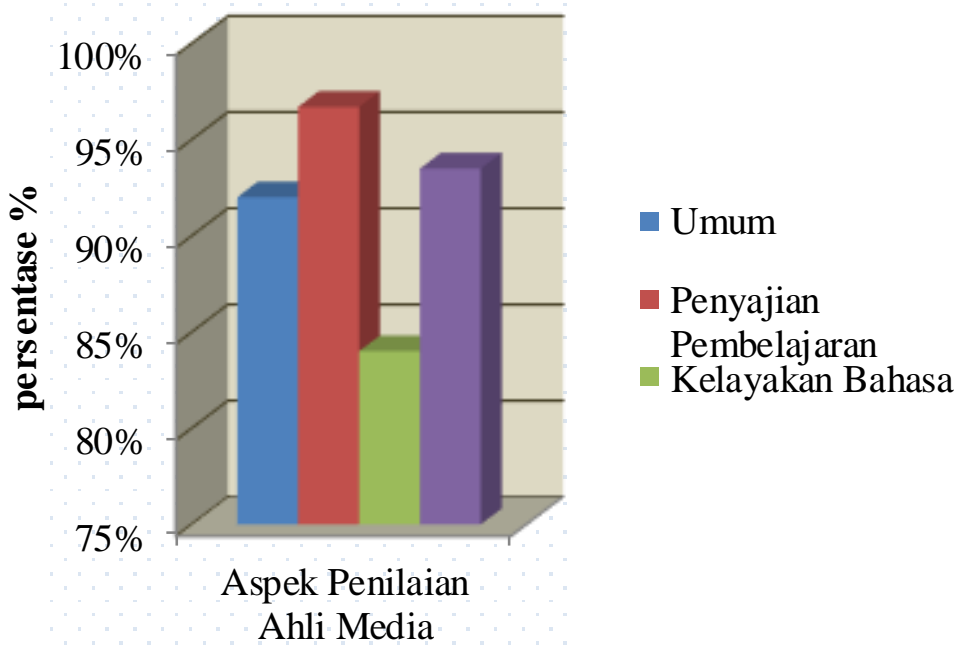

Gambar 1. Diagram Batang hasil validasi produk oleh ahli media

Komentar secara umum dari validator 1 adalah Media layak diujicobakan di lapangan tanpa adanya revisi. Tetapi validator 2 memerlukan revisi adapun beberapa revisi yang dilakukan adalah sebagai berikut:

Tabel 1. Revisi Desain Ahli Media Berdasarkan Validator 2

\begin{tabular}{|c|c|c|}
\hline & ain Sebelum Revisi & Desain Sesudah revisi \\
\hline \multirow[t]{2}{*}{ a) } & Tampilan desain e-book kurang & a) Tampilan desain sudah menarik \\
\hline & \multicolumn{2}{|c|}{ menarik } \\
\hline \multirow[t]{2}{*}{ b) } & Background terlalu ramai & b) Backround sudah tidak terlalu \\
\hline & & ramai \\
\hline c) & Ukuran file terlalu kecil & c) Ukuran file sudah diperbesar \\
\hline
\end{tabular}

\section{Hasil Validasi Materi}

Analisis ahli materi ditinjau dari aspek : 1) aspek umum, 2) aspek substansi materi, dan 3) aspek desain pembelajaran. Validasi dilakukan oleh 2 ahli yang berkompeten pada bidangnya. Berdasarkan perhitungan, diketahui prosentase $=$
$89,2 \%$, setelah dikonversikan dengan tabel konversi skala, prosentase tingkat pencapaian $89,2 \%$ berada pada kualifikasi sangat baik sehingga media pembelajaran layak diuji cobakan. 


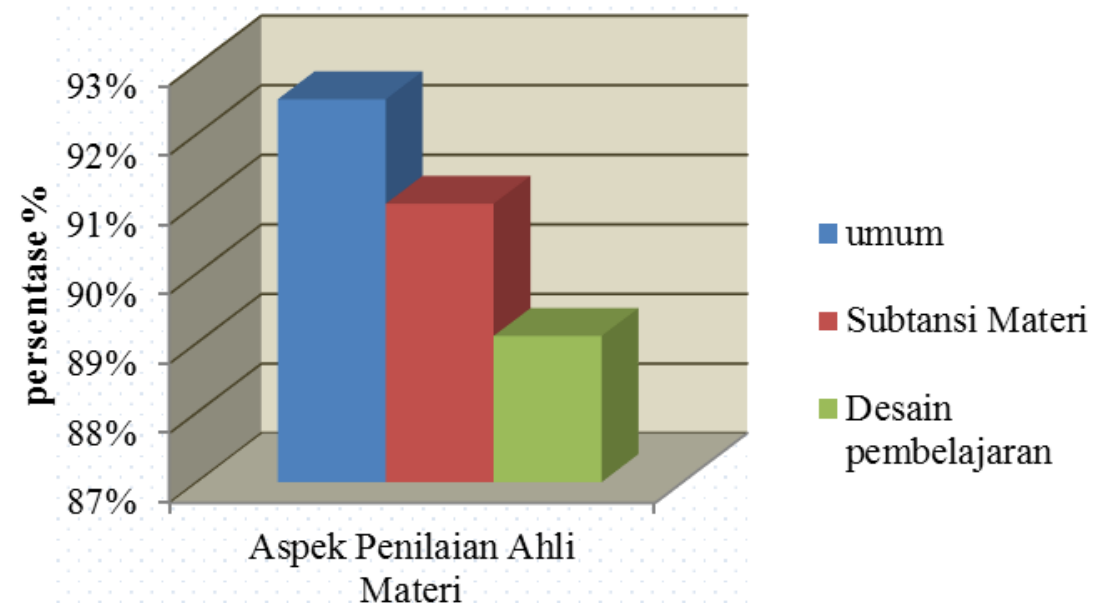

Gambar 2. Diagram batang penilaian produk oleh ahli materi

Sedangkan komentar secara umum dari validator 1 adalah Media layak diujicobakan di lapangan dengan sedikit revisi. Tetapi validator 2 layak diujicobakan tanpa adanya revisi. Adapun revisi tersebut adalah sebagai berikut:

Tabel 2. Revisi Desain Ahli Materi Berdasarkan Validator 1

\begin{tabular}{lcl}
\hline & Desain Sebelum Revisi & Desain Sesudah revisi \\
\hline a) & Contoh soal perlu diperbanyak & a) Contoh soal sudah diperbanyak \\
& lagi dan bervariasi & dan dibuat bervariasi \\
b) & Perkuat kajian teori tentang laporan accounting & b) kajian teori laporan accountting \\
dibuat lebih sistematis & & \\
c) & Format penulisan ada kesalahan & c) Format penulisan sudah diperbaiki
\end{tabular}

\section{Hasil Tanggapan Mahasiswa}

Produk yang diujicobakan berupa e-book dengan software flipbookmaker mata kuliah akuntansi keuangan. E-book ini ditanggapi oleh 25 mahasiswa yang berasal dari jurusan komputerisasi akuntansi. mahaiswa menanggapi e-book ini dengan cara mengisi angket yang diberikan peneliti untuk diisi mahasiswa. Analisis tanggapan mahasiswa ditinjau dari aspek kelayakan penyajian, materi, contoh soal dan latihan soal, serta aspek keingintahuan mahasiswa. 


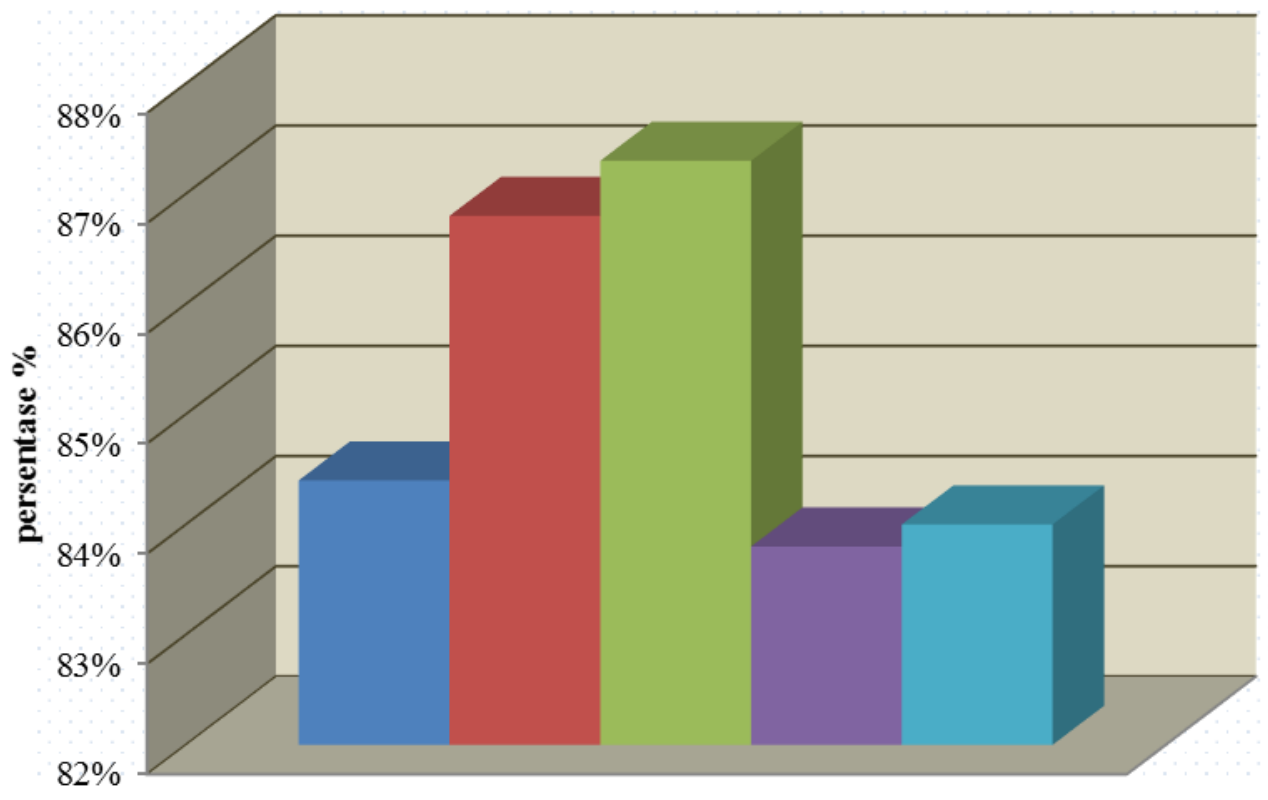

Gambar 3. Diagram Batang angket respon mahasiswa oleh Mahasiswa.

Berdasarkan perhitungan, didapatkan persentase sebesar $85,2 \%$. Setelah dikonversikan, persentase tersebut berada pada kualifikasi sangat baik sehingga e-book layak digunakan sebagai media pembelajaran pada materi pembauatan laporan keuangan.

\subsection{Pembahasan}

Penelitian ini adalah Research and Development yang akan menghasilkan suatu produk. Produk yang dihasilkan dalam penelitian ini adalah media pembelajaran berupa e-book dengan software flipbookmaker pada materi laporan keuangan.

Berdasarkan penilaian dan tanggapan dari ahli media, ahli materi dan hasil respon mahasiswa, secara umum media pembelajaran ini mempunyai keunggulan dibandingkan dengan media pembelajaran konvensional. yang termasuk dalam kualifikasi sangat baik, sehingga media pembelajaran ini layak digunakan dalam pembelajaran akuntansi keuangan.

Uji coba produk dilakukan terahadap 25 mahasiswa. e-book ini memiliki tampilan fisik yang baik dan menarik. Daftar isi dan peta konsep membantu memahami materi. Memiliki tingkat kejelasan yang baik antara petunjuk penggunaan e-book, tujuan pembelajaran, paparan materi, rangkuman, tugas, tes formatif, lembar kerja dan evaluasi dalam e-book. Sehingga uraian materi, contoh, tugas, tes formatif, lembar kerja, dan evaluasi mudah dipahami oleh mahasiswa. Hal tersebut menyatakan bahwa media pembelajaran ini sangat menarik dan digunakan sebagai media pembelajaran yang mendukung dalam pemecahan masalah pembelajaran di kelas.

\section{Kesimpulan dan Saran}

\subsection{Simpulan}

Berdasarkan hasil penelitian dan pembahasan yang telah dilakukan maka dapat diambil kesimpulan sebagai berikut:

1. Dihasilkan pengembangan e-book dengan software flipbookamker yang sesuai untuk pembelajaran mata kuliah akuntansi keuangan dengan model pembelajaran 4-D. Validasi ahli media yang memberikan hasil dengan prosentase yaitu $85,2 \%$ dan ahli materi pembelajaran 
memberikan nilai dengan prosentase 89,2\% dengan aktegori sangat baik, sehibngga produk ebook siap digunakan

2. hasil penilaian dari tanggapan mahasiswa terhadap penggunaan media pembelajaran e-book memberikan hasil dengan prosentase yaitu $85,2 \%$ dengan kategori sangat baik, artinya cocok dengan kebutuhan mahasiswa.

\subsection{Saran}

Diharapkan produk e-book dengan flipbookmaker ini dapat dijadikan buku penunjang bagi dosen dan mahasiswa kompuerisasi akuntansi dalam pembelajaran mata kuliah akunatnsi keuangan, teruatam di STEKOM Semarang.

\section{DAFTAR PUSTAKA}

Arikunto, Suharsimi. 2013. Dasar-Dasar Evaluasi Pendidikan. Jakarta: Bumi Aksara.

Buchori Achmad, dkk. 2014. "Development of Matiklopedia Based Character Building in Yunior High School". International seminar on innovation in mathematics and mathematics education. Diakses November 2014. Yogyakarta state university.

Buchori, Ahmad. 2014. pengembangan bahan ajar matematika berbasis FlipBookmaker untuk membangun peserta didik yang cerdas dan berkarakter. Jurnal Aksioma. volume 6. tahun 2014.

Caroline, Ayoti dan Moses. 2013. "Challenges Facing Teachers In Preparation And Utilization Of Instructional Media In Teaching Kiswahili In Selected Secondary Schools In Kenya”. Journal of advanced research; Vol. 1 Issue 3. Diakses Mei 2013. Kenya: University of science and technology.

Hamdani, 2011. Strategi Belajar Mengajar. Bandung: Pustaka Setia.
Heuvel-Panhuizen, Van den. 1996. Assessment And Realistic Mathematics Education. Utrech: Freudenthal institute. Netherlands.

Russell, James dkk. 2011. Intructional Technology and Media For Learning. Jakarta: Kencana

Saglam, Halil Ibrahim. 2011. “An Investigation On Teaching Materials Used In Social Studies Lesson" Journal of Educational Technology Vol.10 No.1. Diakses January 2011. Turkey: Sakarya University Turkey.

Schunk, Dale. 2012. Learning Theories And Aducational Perspective. Yogyakarta: Pustaka Pelajar.

Schramm, 1984. Media Besar Media Kecil, Alat dan Teknologi untuk Pengajaran, Seri Pustaka Teknologi Pendidikan No. 5. IKIP Semarang Setyosari, Punaji. 2015. Metode Penelitian Pendidikan Dan Pengembangan. Jakarta: Kencana.

Siagian, Sahat. 2014. "Development of Basic Electronic Instructional Module and Trainer". Journal of computer science and information technology Vol. 2 No. 3. Diakses September 2014. University of Medan.

Suarsana. 2013 "Pengembangan E-book Berorientasi Pemcahan Masalah Untuk Meningkatkan Keterampilan Berfikir Kritis Mahasisiwa". Jurnal Vol.2 No.2. Diakses oktober 2013. Singaraja: Universitas pendidikan Ganesha. Wena, made. 2013. "Pengambangan E-book Bermuatan Model Perubahan Konseptual Dalam Pembelajaran Fisika Di SMA". Jurnal Santi aji Pendidikan Vol 1 No 1. Diakses 7 desember 2013. Denpasar: UNMAS. 